LETTERS

\section{Growth Regulator Research}

I read the recent article on plant growth regulator (PGR) research in a Viewpoint by Jonathan Cutting [HortScience 25(12):1471, Dec. 1990]. I wholeheartedly agree that plant physiologists (as basic scientists) and horticulturists should team up to develop these important concepts of learning and practicing how to increase the biomass of our food or other crops on a world-wide basis. However, I wish to add several points that will explain why the teamwork of the 1970 s did not materialize in the 1980 s.

1) The cost of developing and marketing a new PGR or similar pesticidal product (insecticide, fungicide, herbicide, or any other "economic poison") has increased to \$20$\$ 30$ million in the United States alone, and perhaps to much larger amounts on a worldwide basis. Such investments are not easy to find even if the payoff is great.

2) Even re-registration of existing PGRs and similar chemicals cost \$4-\$5 million to provide the necessary toxicological data-gap or to furnish data according to our 1990 standards or needs to know about the potential future risks and benefits. My company has spent and has agreed to spend such large amounts on two postharvest growth regulators for the re-registration process. So you see, some heavy-duty financing and economics are involved here.

3) The third point $I$ have is regarding the extreme "chemophobia" that exists in the world today. The general mass of our population, even in the so-called "developed" countries, is unaware that their food is much safer than it was some 60 years ago. This chemophobia has been promulgated or exaggerated by small segments of our society that are not really interested in feeding the masses or production of abundant "biomass". They are like political zealots or religious fanatics interested in spreading their own dogma or philosophy at the expense of economic disasters or even deadly wars. So, we must educate the masses and clear up or destroy "chemophobia".

4) In my first point, I mentioned the words "economic poison" as a synonym for "pesticides". The governmental agencies rightfully regulate such chemicals to protect the public from any health or environmental hazards. There is nothing wrong with it, ex cept the connotation of these words as perceived is bad. The general mass is made to think that such chemicals are extremely poisonous or dangerous and that the people who sell or use them are motivated with simple benefits of reaping the economical profits only. This perception should or can be changed or altered only by education of the masses - only then can we have continued teamwork by physiologists, horticultur ists, chemists, toxicologists, and economists to produce the abundantly safe cheaper biomass.

5) Cutting's university team or any other similar horticulture group should involve members of other disciplines to carry out their research plans. Or, at least, the team should think about such benefits and risks of commercializing their research efforts prior to execution; then they will be more useful to society as a whole. I hope such teamwork will materialize in our com mon goals in the 1990 s.

B. DAVÉ

3731 Pico Circle LaVerne, CA

\section{Educational Opportunities for Horticulture}

In a blue-ribbon report on the poor state of precollege biology education, the National Research Council (1990) recommended that "because plants are especially easy to grow and care for, students at every grade level should be involved in gardening projects, using outside space, window boxes, or potted plants. The ecological and agricultur al importance of plants should be a major point of emphasis. The historical importance of agriculture in the development of the human race provides an ideal opportuni ty to integrate the social and natural sciences." The report also notes that "The centerpiece of this document... is the need for leadership from the scientific community." To reinforce the need for increased attention to science education, the National Science Foundation (NSF) education budget in creased $46 \%$ from FY90 to FY91 (Palca, 1990), and the NSF considers that "The term 'research' includes projects to improve the teaching and learning of science" (Hershey, 1989). However, plant science societies, such as ASHS, have been very slow to respond to the science education crisis.

The recent surge in availability of precollege plant science education materials with a hands-on emphasis has come mainly from outside the scientific community. The National Gardening Association has received about \$1 million from NSF to develop a hands-on, gardening-centered curriculum for K-8 students (Cohen and Pranis, 1990; Pranis and Hale, 1988). A similar curriculum development project by a private company, LifeLab, has received more than $\$ 2$ million from NSF and \$2.4 million from an educational publisher (Jaffe and Appel, 1990; NSF, 1989). Bonnet and Keen (1989) provide science fair project ideas in botany, although most are horticultural, aimed at 8to 13-year-olds.

ASHS Member Paul Williams heads the Fast Plants program (Williams, 1989) that uses rapid-cycling brassicas as model plants for plant science education at all levels and has received NSF funding. The NSF noted that "an eminent research scientist (Wil- liams) is deeply involved in trying to improve precollege science education.... and is serving as a model for other research scientists" (NSF, 1989). The Crop Science Society of America's lab manual (Vorst, 1990) for junior and senior high school students contains lab exercises similar to those in college plant physiology labs.

The downside to the availability of these materials is the surprisingly many errors and misconceptions that they contain and their general lack of originality. The worst of fender is Bonnet and Keen (1989), which even describes symptoms of plant hydrogen deficiency! Both GrowLab (Cohen and Pranis, 1990) and LifeLab (Jaffe and Appel, 1990) have an exercise demonstrating root hydrotropism, yet "there is no unequivocal evidence for true hydrotropism in plants" (Wareing and Philips, 1981). Except for Fast Plants (Williams, 1989), most of the plant exercises are basically the same as those previously published. The general lack of quality in precollege plant science education materials is not surprising, since there is no formal refereeing process, as in scientific journals, and "most biology textbooks are produced by publishers who are responding to educationally bankrupt market forces... [and]... are written by authors who do not control the content of the books and who are not selected for their knowledge of biology" (National Research Council, 1990).

This situation offers ASHS many opportunities, including the chance to develop truly innovative, scientifically sound educational materials for precollege plant science education. ASHS also could serve as a national referee for educational materials deal ing with plant science, including textbooks, as the National Resource Council (1990) recommends: "The broader scientific community should be engaged nationally in collaboration with teachers in evaluating textbooks and locally in providing advice on textbook adoption."

Potential benefits of these educational activities include improved science literacy, more recognition and prestige for ASHS and horticultural science, more horticulture students, and more financial support for horticulture from a public that is literate about the fundamental importance of horticulture to civilization.

\section{Literature Cited}

Bonnet, R.L. and G.D. Keen. 1989. Botany: 49 science fair projects. TAB Books, Blue Ridge Summet, Pa.

Cohen, J. and E. Pranis. 1990. GrowLab: Activities for growing minds. National Gardening Assn., Burlington, Vt.

Hershey, D.R. 1989. Plant scientists should promote plant science through education. Plant Cell 1:655-656.

Jaffe, R. and G. Appel. 1990. The growing classroom: Garden-based science. Addison-Wesley, New York.

National Research Council. 1990. Fulfilling the promise: Biology education in the nation's 
schools. National Academy Press, Washington, D.C.

National Science Foundation. 1989. Directorate for science and engineering education directory of awards: Fiscal years 1987 and 1988. NSF, Washington, D.C., Publ. 89-18.

Palca, J. 1990. Final verdict on science budget: Not bad at all. Science 250:617-618.

Pranis, E. and J. Hale. 1988. GrowLab: A complete guide to gardening in the classroom. $\mathrm{Na}$ tional Gardening Assn., Burlington, Vt.

Vorst, J.J. (ed.). 1990. Experiments in crop science. Crop Sci. Soc. Amer., Madison, Wis.

Wareing, P.F. and I.D.J. Phillips. 1981. Growth and differentiation in plants. 3rd ed. Pergamon, New York.

Williams, P.H. 1989. Wisconsin fast plants manual. Carolina Biological Supply, Burlington, N.C.

DAVID R. HERSHEY Dept. of Horticulture Univ. of Maryland College Park

\section{Ad-Hoc Committee Report on DOS in Horticulture Departments}

The ASHS Ad-Hoc Committee Report on Integration of Discipline-oriented Scientists into Horticulture Departments [HortScience 25(11):1347-1358, Nov. 1990] is a very important topic to the future of horticulture departments, and the committee presented a good report from the point of view of the needs of the new faculty members with this background. However, the committee did not discuss sufficiently the obligations of these new faculty members to the department.

It is not sufficient that they do a good job of applying molecular biology to a horticultural crop(s) that is important to their state. They must learn the horticulture and physiology of these crops. This is essential to the future of horticulture departments.

Departments are not training or hiring $\mathrm{PhD}$ horticulturists. Rather, specialists are being trained in physiology, biochemistry, or molecular biology. Commodity groups are not going to directly fund or support state funding of departments that are not solving their problems. Young faculty must aggressively learn about the problems and nature of the industry they are supporting. This is important for their future research projects and eventually for the teaching and extension they must do. Just as faculty are expected to keep up-to-date in their specialty field and expand their learning into other fields that can be applied to problems as partial answers develop, so must new faculty expand their horticultural knowledge until they are horticulturists as well as molecular biologists. Then they can fully communicate and participate in the department. The few horticulturists left in some departments need to be willing to help in this process, but it is the new faculty member who should seek this knowledge and cooperative activities.
This process is critically important to the future of horticulture. More and more horti culture department faculty are narrow specialists in plant physiology, biochemistry, or molecular biology, with little or no horticul tural principles and practices background. Ten to 15 years from now, there will be no one to teach traditional horticulture classes in degree programs.

If departments cannot relate to the problems of the horticultural industry in their state and cannot train new people for these industries, there will not be a need for all the biochemists, molecular biologists, etc. now being hired by all horticulture departments. I think the future employment of these individuals depends on their becoming good horticulturists.

$$
\begin{array}{r}
\text { L.G. ALBRIGO } \\
\text { Citrus Research and Education Center } \\
\text { IFAS, Univ. of Florida } \\
\text { Lake Alfred }
\end{array}
$$

\section{The Corporate University ASHS Presidential Address}

I am sure that, after your address at the ASHS Annual Meeting in Tucson and the publication of that address in HortScience [25(11):1330-1340, Nov. 1990], you have received and will receive considerable mail. That you are opinionated and controversial is an accepted fact. However, you have the rare quality of supporting your opinions with well-reasoned thought so that even those who might disagree have to grant you immense respect. I happen to be one who, for the most part, agrees with your logic.

I was impressed with the wealth of background and other relevant information you presented in your address. I feel compelled, as Lincoln so eloquently stated at Gettysburg, not to judge or criticize until I put forth the same effort. You obviously put a lot of blood, sweat, and toil, and perhaps tears, into the preparation of this treatise.

You have also obviously found the proper nerve roots, the spinal cord of the problem with the university systems. You are absolutely correct in saying that the driving force in research today is the source of fund ing. The short-term concept of planning is also very evident. However correct you may be in your analysis, I fear that the universities, like the governments, will not change in the foreseeable future. I would like to believe that we, the staff, have the power to in fluence the direction of the research. I am afraid that the institutions are too tightly linked to politics and I do not believe our governmental problems will change short of a national economic collapse.

You have incited my frustrations again, but you also have done a beautiful job of laying out the historical basis for the problem and, most importantly, have offered solutions. You are to be commended for laying out your perception of the situation with clarity.
Thanks for stimulating our sometimes dormant minds.

\section{HOWARD L. MALSTROM \\ Texas A\&M Experiment Station Texas A\&M Univ. El Paso}

This is to thank you again for the courage to stand up and share your thoughts and concerns about the university. When you were speaking, I was reminded of Robert Pirig's classic, Zen and the Art of Motorcycle Maintenance. It offered a similar reflection on universities, science, and rational thought, in general. He also argued that socalled scientists have become mere technicians.

JOHN M. GERBER Univ. of Illinois

Urbana

Your article on the corporate university says very well some of the thoughts I have had-although I have had less experience than you with land-grant universities. There are also troubles at private universities; venerable fields such as mathematics go in chiefly for technicalities.

Saunders MacLane Dept, of Mathematics The Univ. of Chicago Chicago, Ill.

I much regret that I was not at the Tucson meeting to hear this. However, thanks to your more-than-timely publication, I am already distributing copies.

Your strong case for a balanced humanities/science education brought back a classic reviewer's quibble.

The first sentence of my Viewpoint in HortScience in 1980 [15(3):228-229, June 1980] reads: "It is a foolish young scientist who does not soon learn that the Court of Inquisition still sits in judgment on the unorthodox." One eamest young $\mathrm{PhD}$ reviewer wrote: "Explain what is meant by 'the Court of Inquisition'." $\mathrm{He}$ has too much company!

WILLIAM GRIERSON Winter Haven, Fla.

It is vintage George Martin! I got an advance look at your Presidential Address from a copy Conrad Link had in the "Emeritus Room" at the Univ. of Maryland before receiving my copy. I thought I would read it in pieces, but when I finished chapter 23, I simply could not put it down and went on through the last 11 chapters. It is well-organized, beautifully done. I have been over it twice since, and now must respond for it stirs up in my mind a matter I have meditated on for many years. 
I have kept a file for nearly 40 years that I entitled "American Manners and Morals". I taught the same sophomore course for 31 years, with a senior and graduate course in alternate years. In the 31 classes of sophomore-level work, I saw a marked shift in my students from 1952 to 1982 . In the 1950 s, they were perhaps no better motivated, but they could spell, did not cut class, etc. Beginning in the late 1960 s, coincident with the appearance of the hippies, etc., students were less well-prepared for college work, could not spell, had a short attention span, and did not do required library reading. Perhaps more significant, my last doz-en years were punctuated with whining that my exams were too hard. I never gave a true-false or a multiple choice question. The students were told this on the first day and warned that they had to study the stuff for my exams. I read 20 years ago that the average incoming freshman came from a background of 20,000 hours of television. I did not believe that, and checked it out with my four children (who were limited to 1 hour of television per day-approved programs only), and they estimated the figure to be close to the truth.

So, I have been concerned for a long time about the dilution of our whole education process from the first grade on. Even in graduate school I saw young men and women go out with advanced degrees who did not have enough sense to come in out of the rain, never should have been accepted in the first place, and should have been dropped along the way. I have a son-in-law who teaches physics and chemistry in high school and learned from him that they cannot fail anyone-promotion is automatic (it is called "social promotion"). Now that school system is offering different terminal certificates-a diploma, or a certificate certifying 12 years of attendance. Automatic promotion? What kind of scholarship is that? We have remedial courses larding our college course offerings now, and demands are growing for the institutions to "increase retention rates". Remedial work should be done in junior high, not in college. I regard the whole process as ludicrous. People who are not prepared academically for college should not be admitted to college, period.
I came up to your address with this in my background. In re-reading your paper, I concur virtually all the way. You are so right in so many aspects of your discussion. I think you have delineated well the corporate university and the university. You challenge your readers to pursue this unique and yet practical goal, and you seem to have funding on your mind as the chief hurdle. I tend to think of others. For example, your second factor, reading, comes to mind. I see no substitute for this, and strongly endorse your statement "reading provides for study in-depth of ideas and concepts, something often missing in this era of 20 -second sound bites." I think lack of reading is an enormous barrier to education today. Children who grow up with television as a babysitter are not likely to read much-then or ever. I have seen this in my undergraduate students, and even in some of my graduate students. I ask myself as I study your piece, "How is one going to educate if the joy of reading is not instilled early?"

Despite the difficulties, the concept of the university is worthwhile. You say "a few is enough". Amen. Indeed, if we could establish one of significance in the next 50 years, perhaps we will make some headway in the right direction. I can only hope your address winds up in the right hands, that some smart people, such as your own Charlie Hess, can do something about it.

As for creativity, I concur with your reaction to the word in promotion and tenure committees. I have had the same experience, especially in upper-level (college and university) groups beyond the department. Yet, I would argue that society has broadened the meaning of the word beyond your thresholds. I have regarded you as being a creative president. For, as you say, "the creative individual brings something into exis tence that was not there before". You are imaginative, and thus creative. Surely your proposal regarding page charges is an example, as are your proposals in your address. (Was it you or Roy Larson who was injured in that discussion of page charges vs. dues in the Program \& Abstracts? I could not tell from the picture who got off the first shotgreat humor...that was creative.)

I thought John Bukovac was creative when, after much thought, he created the Evaluation Task Force, which directed us to take the Society apart and put it together in a fashion that would accommodate all Members and set the organizational pattern for years to come. John Bukovac did that... he was creative. If you have never read F.C. Bradford's 1942 Presidential Address (Proc. Amer. Soc. Hort. Sci. 40:599-606), I sug gest it to you. He was creative.

I am sure you will get many and varied responses to your marvelous address. This is one of them. Best wishes, and thanks for a marvelous year as our President.

ART THOMPSON

Dept. of Horticulture Univ. of Maryland

College Park

\section{Corrigendum}

-In the article "Lisianthus Growth and Flowering Responses to Uniconazole", by Terri Woods Starman [HortScience 26(2):150-152, Feb. 1991], the author wishes to note an error in the reported concentrations of uniconazole medium drench treatments. The rates reported are in mg liter $^{-1}$, not $\mathrm{mg}$ a.i./pot. Equivalent concentrations are:

\begin{tabular}{|c|c|}
\hline mg.liter $^{-1}$ & mg a.i.jpo \\
\hline 0.00 & 0.00 \\
\hline 0.20 & 0.025 \\
\hline 0.40 & 0.05 \\
\hline 0.80 & 0.10 \\
\hline 1.60 & 0.20 \\
\hline
\end{tabular}

Therefore, the recommended medium drench concentration that is reported in the abstract and several times throughout the article is $1.60 \mathrm{mg} \cdot \operatorname{liter}^{-1}(0.20 \mathrm{mg}$ a.i./pot $)$.

- Photographic credit for the front and back covers of the January 1991 issue of HortScience [26(1):2, 91, Jan. 1991] should be given to: Jerry A. Payne, USDA, Southeastern Fruit and Tree Nut Research Laboratory, P.O. Box 87, Byron, GA 31793. 